\title{
PEMBUATAN ALAT PENDETEKSI GEMPA MENGGUNAKAN ACCELEROMETER BERBASIS ARDUINO
}

\author{
1) Nuzul Imam Fadlilah, ${ }^{2)}$ Ahmad Arifudin \\ Teknik Informatika, AMIK BSI Purwokerto \\ 1) nuzul.nfh@bsi.ac.id \\ 2) ahmadarf1406@gmail.com
}

\begin{abstract}
The development of technology in today is very rapid, so encouraging many parties to develop or even create technology that simplify human work, both software (software) and hardware (hardware) is certainly useful for humans. Reported from BMKG data that counted from January to April 2017 has occurred earthquake as much as 2555 times the earthquake in Indonesia and surrounding areas, both small to medium earthquakes. Earthquake detection equipment is something that is needed by residents who are in earthquake-prone areas or not, this is to anticipate the loss of life. That's why the author tries to make the final task about earthquake detection equipment that uses arduino-based 3accelerometer sensor that is currently required by the population. This earthquake detection tool will work automatically in case of earthquake, with the earthquake detector is the best solution to help reduce the number of casualties because this tool can be used in various places such as office buildings or housing.
\end{abstract}

\section{Keywords: Earthquake Detection, Arduino, Accelerometer}

\begin{abstract}
Abstrak - Perkembangan teknologi pada jaman sekarang sangat pesat sehingga mendorong banyak pihak untuk mengembangkan atau bahkan menciptakan teknologi yang mempermudah pekerjaan manusia, baik perangkat lunak (software) maupun perangkat keras (hardware) yang tentunya berguna bagi manusia. Dilansir dari data BMKG bahwa terhitung dari Januari sampai April 2017 sudah terjadi gempa bumi sebanyak 2555 kali gempa di indonesia dan sekitarnya, baik gempa yang skala kecil sampai sedang. Alat pendeteksi gempa adalah sesuatu yang diperlukan oleh penduduk yang berada di daerah rawan gempa maupun tidak, hal ini untuk mengantisipasi jatuhnya korban jiwa. Untuk itulah peneliti mencoba menyusun penelitian mengenai alat pendeteksi gempa yang menggunakan sensor 3accelerometer berbasis arduino yang pada saat ini dibutuhkan oleh penduduk. Alat pendeteksi gempa ini akan bekerja secara otomatis jika terjadi gempa, dengan adanya alat pendeteksi gempa ini merupakan solusi terbaik untuk membantu menekan jumlah korban jiwa karena alat ini bisa digunakan di berbagai tempat seperti bangunan perkantoran atau perumahan.
\end{abstract}

\section{Kata Kunci: Deteksi Gempa, Arduino, Accelerometer}

\section{A. PENDAHULUAN}

Perkembangan teknologi pada jaman sekarang sangat pesat sehingga mendorong banyak pihak untuk mengembangkan atau bahkan menciptakan teknologi yang mempermudah pekerjaan manusia, baik perangkat lunak (software) maupun perangkat keras (hardware) yang tentunya berguna bagi manusia.

Gempa bumi untuk wilayah Indonesia merupakan masalah yang sering muncul sebagai salah satu sumber bencana alam. Gempa adalah bergetarnya bumi karena peristiwa pelepasan energi regangan elastis batuan di dalam bumi yang disebabkan oleh patahan atau pergeseran lempeng bumi. Semakin besar energi yang dilepaskan semakin besar pula gempa yang terjadi. Indonesia merupakan negara yang rawan gempa hal itu di sebabkan karena Indonesia terletak diantara pertemuan tiga lempeng tektonik dunia yaitu lempeng Eurasia, lempeng Pasifik dan lempeng
Australia. Terhitung dari Januari sampai April 2017 sudah terjadi gempa bumi lebih dari 2000 kali gempa di indonesia dan sekitarnya, baik gempa yang skala kecil sampai sedang. Perkembangan peralatan pendeteksi banyak sekali bermunculan. Program pemerintah untuk antisipasi penanggulangan atau mencegah timbulnya korban dari bencana menjadikan alat pendeteksi gempa menjadi alat yang saat ini dibutuhkan dan efektif. Dengan adanya alat pendeteksi gempa bumi, dapat mengantisipasi atau menekan jatuhnya korban jiwa akibat gempa bumi, hal ini sangat yang diperlukan oleh penduduk baik yang berada di daerah rawan gempa maupun daerah yang jarang terjadi gempa bumi.

\section{B. TINJAUAN PUSTAKA}

Perangkat keras adalah salah satu atau bagian dari sebuah komputer yang sifat alatnya bisa dilihat dan diraba secara langsung atau yang berbentuk nyata, yang berfungsi untuk 
mendukung proses kerja komputer atau komputerisasi.

Contoh dari perangkat keras yaitu:

1. input device: perangkat input atau masukan.

2. proses device: perangkat yang menjalankan proses sistem pada komputer.

3. output device: perangkat keluaran yang menghubungkan sistem pada komputer.

4. storage device: perangkat untuk menyimpan.

Diantara bagian-bagian dari komponen input device, proses device, output device, storage device, terdapat komponen elektronika yang digunakan. Komponen elektronika terbagi menjadi 2 komponen yaitu:

1. Komponen pasif

Komponen pasif adalah komponen yang dapat bekerja tanpa sumber tegangan.

2. Komponen aktif

Komponen aktif adalah komponen yang tidak dapat bekerja tanpa sumber tegangan.

Komponen perangkat keras yang digunakan dalam pembuatan alat ini antara lain:

\section{Teori IC}

Menurut Moch. Choiril Anam (2008:33) mengemukakan bahwa, "Integrated Circuit (IC) sebenarnya adalah suatu rangkaian elektronik yang dikemas menjadi satu kemasan yang kecil". Beberapa rangkaian yang besar dapat diintegrasikan menjadi satu dan dikemas dalam kemasan yang kecil.Suatu IC yang kecil dapat memuat ratusan bahkan ribuan komponen.

\section{IC Regulator}

Voltage regulator atau pengatur tegangan adalah salah satu rangkaian yang sering dipakai dalam peralatan elektronika. Fungsi voltage regulator adalah untuk mempertahankan atau memastikan tegangan pada level tertentu secara otomatis. artinya, tegangan output (keluaran) DC pada voltage regulator tidak dipengaruhi oleh perubahan tegangan input (masukan), beban pada output dan juga suhu.

\section{IC MCP 3204}

Pada modul accelerometer, pin AOX pada $\mathrm{H} 48 \mathrm{C}$ dihubungkan ke $\mathrm{CHO}$ dari MCP3204, AOY pada $\mathrm{H} 48 \mathrm{C}$ terhubung dengan $\mathrm{CH} 1$ dari MCP3204, AOZ pada H48C terhubung dengan $\mathrm{CH} 2$ dari MCP3204 dan Vref pada H48C terhubung dengan $\mathrm{CH} 3$ dari MCP3204.

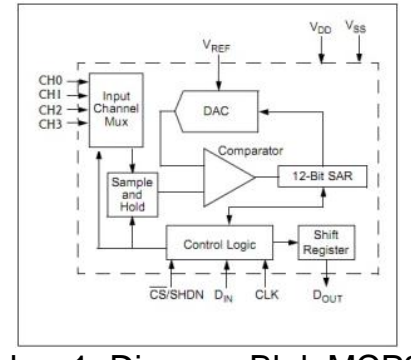

Gambar 1. Diagram Blok MCP3204

\section{FT232R}

FT232R merupakan IC pengubah sinyal USB ke Serial UART (Universal Asynchronous Reciever Transmiter).

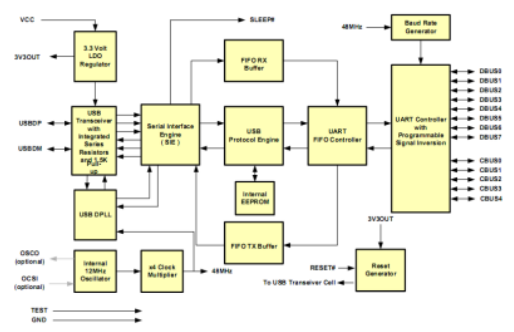

Gambar 2. Blok diagram IC FT232R

\section{Sumber Tegangan}

Sumber tegangan atau catu daya atau sering disebut dengan power supply adalah sebuah piranti yang berguna sebagai sumber listrik untuk piranti lain. Pada dasarnya catu daya bukanlah sebuah alat yang menghasilkan energi listrik saja, namun ada beberapa catu daya yang menghasilkan energi mekanik, dan energi yang lain. Daya untuk menjalankan peralatan elektronik dapat diperoleh dari berbagai sumber. Baterai dapat menghasilkan suatu GGL DC dengan reaksi kimia. Pada intinya semua power supply atau catu daya mempunyai fungsi yang sama yaitu sebagai penyearah dari AC ke DC.

\section{Resistor}

Menurut Moch. Choiril Anam (2008:9) mengemukakan bahwa, "Hambatan adalah komponen elektronika yang selalu digunakan dalam setiap rangkaian elektronika karena dia berfungsi sebagai pengatur arus listrik". Kristal frekuensi atau sering disebut dengan kristal kwarsa adalah komponen/part elektronik yang berfungsi sebagai resonator dan mempunyai frekuensi resonansi tertentu dalam range yang sangat sempit. Frekuensi resonansi kristal frekuensi itu dicantumkan di badan logam kristal dalam bentuk tulisan angka-angka

Tabel 1. Kode Warna Resistor

\begin{tabular}{|c|c|c|c|}
\hline \multirow{3}{*}{ Warna } & \multicolumn{3}{|c|}{ Gelang ke } \\
\cline { 2 - 4 } & $\begin{array}{c}1 \\
\text { dan }\end{array}$ & 3 & 4 \\
\hline
\end{tabular}




\begin{tabular}{|l|c|l|c|}
\hline Hitam & 0 & X 1 & $1 \%$ \\
\hline Coklat & 1 & X 10 & $2 \%$ \\
\hline Merah & 2 & X 100 & $2 \%$ \\
\hline Jinggaa & 3 & X 1000 & - \\
\hline Kuning & 4 & X 10000 & - \\
\hline Hijau & 5 & X 100000 & - \\
\hline Biru & 6 & X 1000000 & - \\
\hline Ungu & 7 & X 10000000 & - \\
\hline Abu-abu & 8 & $\begin{array}{l}\text { X } \\
100000000\end{array}$ & - \\
\hline Putih & 9 & $\begin{array}{l}\text { X } \\
1000000000\end{array}$ & - \\
\hline & & & \\
\hline Emas & - & X 0.1 & $5 \%$ \\
\hline Perak & - & X 0.01 & $10 \%$ \\
\hline $\begin{array}{l}\text { Tidak } \\
\text { berwarna }\end{array}$ & - & - & $20 \%$ \\
\hline
\end{tabular}

\section{Kapasitor}

Menurut Moch. Choiril Anam (2008:19) mengemukakan bahwa, "Kondensator (Capasitor) adalah suatu alat yang dapat menyimpan energi di dalam medan listrik, dengan cara mengumpulkan ketidak seimbangan internal dari muatan listrik". Untuk mengetahui besarnya nilai kapasitas atau kapasitansi pada kapasitor dapat dibaca melalui kode angka pada badan kapasitor tersebut yang terdiri dari 3 angka. Angka pertama dan kedua menunjukkan angka atau nilai, angka ketiga menunjukkan faktor pengali atau jumlah nol, dan satuan yang digunakan ialah pikofarad $(\mathrm{pF})$. Pada badan kapasitor tertulis angka 103 artinya nilai kapasitas dari kapasitor tersebut adalah $10 \times 103 \mathrm{pF}=10 \mathrm{x}$ $1000 \mathrm{pF}=10 \mathrm{nF}=0,01 \mu \mathrm{F}$.

\section{Kristal}

Kristal frekuensi atau sering disebut dengan kristal kwarsa adalah komponen/part elektronik yang berfungsi sebagai resonator dan mempunyai frekuensi resonansi tertentu dalam range yang sangat sempit. Frekuensi resonansi kristal frekuensi itu dicantumkan di badan logam kristal dalam bentuk tulisan angka-angka.

\section{USB}

USB (Universal Serial Bus) merupakan hasil kesepakatan raksaksa-raksaksa industri komputer, antara lain Compaq, DEL, IBM, Intel, Microsoft, NEC dan Northern Telecom selama bertahun-tahun, untuk menentukan standar baru menghubungkan komputer dengan peralatan eksternal yang dinamakan sebagai Universal Serial Bus (USB).

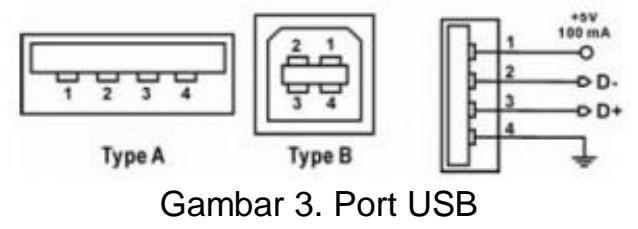

10.Sensor Accelerometer

Accelerometer $\mathrm{H} 48 \mathrm{C}$ merupakan sensor percepatan yang mampu mendeteksi pergerakan dari 3 sumbu yaitu $x, y$, dan $z$. Sensor ini memberikan keluaran berupa data digital hasil konversi tegangan dengan resolusi ADC 12 bit. Percepatan tiap sumbuG dapat dihitung dengan persamaan berikut :

$$
G=(\text { Axis }-v R e f) x 0,0022
$$

Keterangan :

$\mathrm{G} \quad=$ Percepatan

Axis = Tegangan keluaran tiapsumbu

vRef $=$ Tegangan referensi ADC

Fungsi pin CLK adalah sebagai synchronous clock input karena penggunaan bersama jalur data DIO. Sedangkan CS merupakan pin chip select yang digunakan untuk memilih modul yang digunakan apabila modul yang dipakai lebih dari satu.

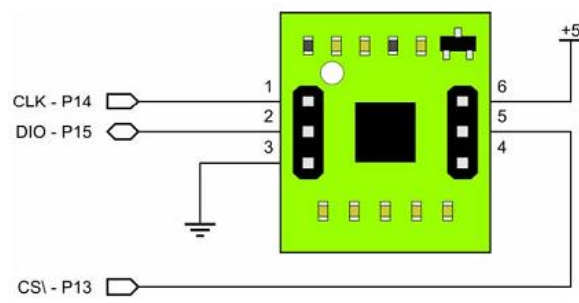

Gambar 4. Skematik konfigurasi sederhana dari $\mathrm{H} 48 \mathrm{C}$

Prinsip pengiriman dan penerimaan data dari $\mathrm{H} 48 \mathrm{C}$ adalah dengan menggunakan teknik geser keluar (shift out) untuk mengirim data, dan teknik geser ke dalam (shift in) untuk menerima data dari kontroler (host). Pada H48C terdapat zeroG detector untuk kalibrasi perhitungan. Pada kondisi jatuh bebas, output zeroG bernilai 3.3V. Prinsip kerja sensor ini adalah seperti di tunjukkan oleh gambar 4 .

Sensor menghasilkan panas yang mana jika dimiringkan maka panas tersebut akan memanasi bagian pinggir sensor yang merupakan bahan seperti thermocoupler. sehingga jika dipanaskan akan menghasilkan perubahan dan perbedaan panas yang mengakibatkan terjadinya perubahan tegangan yang nantinya dimasukkan kedalam ADC.

Sensor accelerometer 3 sumbu ini memiliki sifat pergerakan roll, pitch dan yaw. Sifat ini merupakan sifat pergerakan terhadap sumbu X, 
$Y$ dan $Z$ yang telah disesuaikan dengan titik gravitasi bumi. Sumbu $X$ merepresentasikan gerakan perputaran. Sumbu merepresentasikan gerakan terhadap kemiringan pada sumbu $Y$, Sumbu $Z$ merepresentasikan gerakan menoleh atau perbelokan terhadap bidang.

\section{Buzzer}

Buzzer adalah sebuah komponen elektronika yang berfungsi untuk mengubah getaran listrik menjadi getaran suara

\section{Arduino}

Saat ini ada banyak mikrokontroler maupun platform mikrokontroler tersedia, misalnya saja Basic Stamp-nya Parallax, BX-24-nya Netmedia. Semua alat-alat tersebut bertujuan untuk menyederhanakan berbagai macam kerumitan maupun detil rumit pada pemrograman mikrokontroler sehingga menjadi paket mudah digunakan (easy-to-use).

Arduino juga menyederhanakan proses bekerja dengan mikrokontroler, dibandingkan dengan mikrokontroler, arduino memiliki kelebihan yaitu perangkat lunak dan perangkat kerasnya open source, pemrogramannya mudah, dan harganya murah. Kontroler yang digunakan merupakan kit mikrokontroler arduino board tipe deumilanove dengan mikrokontroler Atmega328.

\section{Ic 328p}

IC 328p adalah mikrokontroler yang berada pada papan arduino. Mikrokontroler merupakan komponen utama yang berfungsi untuk mengolah informasi yang diperoleh, kemudian diproses untuk mengambil kesimpulan respon apa yang akan dilakukan oleh sistem

Sebuah mikrokontroler memiliki minimal tiga blok penting yakni :

a) CPU (Cental Processing Unit)

Yakni unit dimana terjadinya operasi aritmatika ataupun logika serta registerregister geser. Semua perhitungan sistem kontrol dan operasi input/output terjadi di bagian ini.

b) Memori

Merupakan unit penyimpanan data. Instruksi-instruksi yang paling dasar di set pada high level program, yang terinstal dalam Read Only Memory (ROM). Sedangkan program-program logic disimpan pada Electrically Eraseble Permanent Read Only Memory (EEPROM).

c) I/O Unit (Unit Input / Output)

Merupakan bagian yang bertugas melakukan komunikasi dengan dunia luar. Unit input bertugas dalam memproses masukan dari dunia luar untuk diproses lebih lanjut oleh CPU. Sedangkan unit output merupakan bagian yang bertugas sebagai perantara CPU melakukan operasi terhadap piranti luar yang merupakan unit aktuator dari sebuah sistem ataupun unit HMI (Human and Machine Interfaces) seperti LCD display.

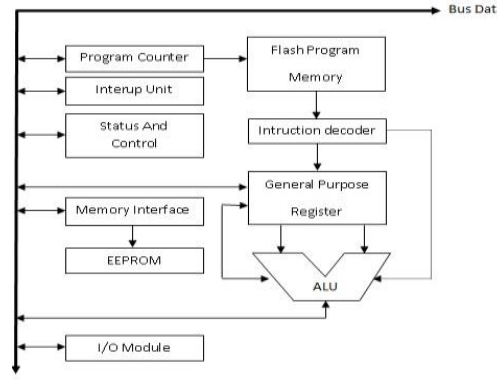

Gambar 5. Blok diagram arsitektur dasar mikrokontroler

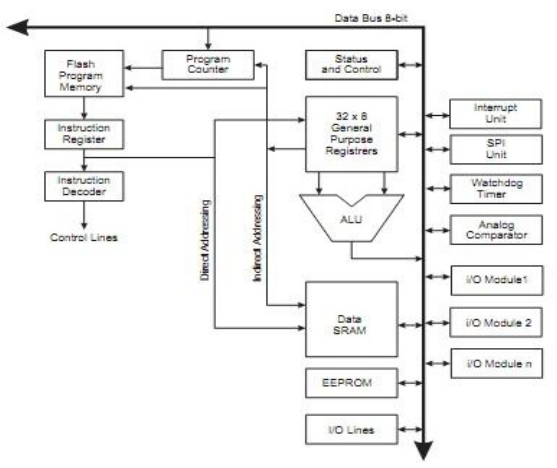

Gambar 6. Arsitektur mikrokontroler ATmega8 Komponen perangkat lunak yang digunakan dalam pembuatan alat ini antara lain:

1. Delphi adalah suatu bahasa pemrograman (development language) yang digunakan untuk merancang suatu aplikasi program. Keguanaan dari delphi sendiri adalah:

a) IDE (integrated Development Environment.)

b) Proses kompilasi cepat.

c) Mudah digunakan, source code delphi yang merupakan turunan dari pascal.

d) Bersifat multi purphase, artinya bahasa pemrograman delphi dapat digunakan untuk mengembangkan berbagai keperluan pengembangan aplikasi.

Dalam delphi program yang digunakan adalah bahasa pemrograman pascal. Pascal adalah salah satu bahasa pemrograman komputer yang umumnya digunakan sebagai pengantar untuk mulai belajar algoritma dan pemrograman. Pascal relatif mudah dipelajari karena perintah-perintahnya yang mirip dengan bahasa inggris sehari-hari seperti begin, end, write, dan read.

Contoh syntak bahasa pemrograman pascal: 


\section{1) procedure}

TForm1.Timer1Timer(Sender:

TObject);

begin

Panel3.Caption:=formatDateTim e('hh:mm',now);

Label8.Caption:=formatDateTim

end;

e('dd/mm/yyyy',now);

2) repeat

comport1.ReadStr(ch,1);

data := data + ch;

end;

\section{Arduino IDE}

Untuk memprogram board arduino, kita butuh aplikasi IDE (Integrated Development Environment) bawaan dari arduino. Aplikasi ini berguna untuk membuat, membuka, dan mengedit source code. Dalam Arduino menggunakan bahasa pemrograman $\mathrm{C}++$. Bahasa pemrograman adalah notasi yang digunakan untuk menulis program (komputer). Bahasa ini dibagi menjadi tiga tingkatan yaitu bahasa mesin, bahasa tingkat rendah dan bahasa tingkat tinggi. Bahasa mesin (machine language) berupa micro instruction atau hardwire. Programnya sangat panjang dan sulit dipahami.

Di samping itu sangat tergantung pada arsitektur mesin. Keunggulannya adalah prosesnya sangat cepat dan tidak perlu interpreter atau penterjemah Bahasa tingkat rendah (low level language) berupa macro instruction (assembly). Bahasa pemrograman yang lebih mudah dipelajari adalah bahasa pemrograman aras tinggi. Disebut atas tinggi karena bahasanya mendekati level bahasa manusia sehingga lebih mudah dipahami.

Contoh syntak $\mathrm{C}++$ :

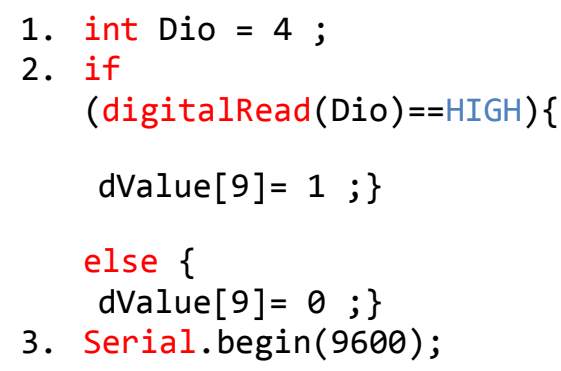

\section{METODE PENELITIAN}

Metode yang akan digunakan dalam pembuatan alat ini, yaitu:

\section{Metode Observasi}

Melakukan penelitian dan percobaan dalam pembuatan alat tersebut sehingga menghasilkan data yang akurat dalam

pembuatan alat pendeteksi gempa menggunakan 3Akselerometer berbasis Arduino.

\section{Metode Kepustakaan}

Mempelajari buku-buku yang relevan guna memberi pemahaman yang lebih baik terhadap topik penelitian dan memperkaya pengetahuan yang diperlukan di dalam pembahasan masalah-masalah yang terjadi dan berhubungan dengan pembuatan sistem deteksi gempa berbasis Arduino.

\section{Metode Wawancara}

Melakukan wawancara terhadap pakar kegempaan dari institusi BMKG sebagai referensi.

\section{HASIL DAN PEMBAHASAN}

Langkah awal adalah baterai dihubungkan ke arduino. Pada saat pertama kali start, bootloader arduino akan melakukan inisialisasi proses start up. Proses ini ditandai dengan berkedipnya LED indikator arduino sebanyak 7 kali dengan durasi " $O N$ " selama $200 \mathrm{~ms}$ dan "OFF" selama 200ms. Jumlah kedipan LED indicator ini merupakan sinyal penanda proses booting arduino dan inisialisasi UART arduino dengan rincian 3 kali kedip untuk proses booting dan 4 kali kedip untuk proses inisialisasi UART.

Setelah proses inisialisasi kemudian arduino akan menjalankan program aplikai pengguna dalam hal ini program deteksi gempa bumi. Program deteksi gempa dimulai dengan pembacaan data akselerometer (sensor $\mathrm{H} 48 \mathrm{C}$ ) secara terus menerus, data percepatan pada masing-masing sumbu dikirim ke PC untuk diproses oleh software interface melalui jalur UART. Apabila pada salah satu sumbu terjadi perubahan nilai percepatan melebihi dari nilai "set_poin" maka buzzer pada alat deteksi gempa akan berbunyi.

\section{Catu Daya}

Catu daya utama menggunakan battery 7,2 Volt kemudian dihubungkan dengan arduino. Blok power supply internal pada arduino terdapat regulator 5 Volt yang akan mengubah tegangan 7,2 Volt menjadi 5 Volt, sehingga sesuai dengan nilai tegangan kerja kontroler arduino, sensor dan actuator yang digunakan.

Rangkaian regulator yang ada pada arduino board adalah sebagai berikut:

Prinsip kerja rangkaian diatas adalah tegangan input dari baterai kemudian diturunkan menjadi tegangan 5 Volt ter-regulasi oleh IC LDO (Low Drop Out) regulator MC33269D.

\section{Input}


Sensor H48C terhubung langsung ke arduino dengan konfigurasi sebagai berikut.

a) pin 1 sensor $\mathrm{H} 48 \mathrm{C}$ (pin clock) terhubung dengan arduino pin 5

b) pin 2 sensor $\mathrm{H} 48 \mathrm{C}$ (pin $\mathrm{DIO}$ ) terhubung dengan arduino pin 4

c) pin 5 sensor H48C (pin CS / Chip Select) terhubung dengan arduino pin 6 .

d) pin 6 sensor $\mathrm{H} 48 \mathrm{C}$ terhubung dengan pin VCC 5 Volt arduino.

e) pin 3 sensor $\mathrm{H} 48 \mathrm{C}$ terhubung dengan GND.

\section{Proses}

Rangkaian proses terletak dipusat pengendali yaitu board arduino. Proses dapat dilakukan setelah komponen input memberikan data input ke arduino dan perintah program intruksi telah dimasukan kedalam arduino.

\section{Output}

a) Buzzer

Output yang digunakan adalah buzzer dengan spesifikasi tegangan kerja 5 volt dan arus optimal 30mA. . Sebenarnya spesifikasi buzzer yang digunakan masih dapat ditangani langsung oleh pin output arduino karena pin output arduino sendiri mempunyai spesifikasi tegangan maksimal 5 volt dan arus maksimal 40mA. Akan tetapi jika terhubung langsung dengan pin output arduino akan menyebabkan konsumsi arus arduino tinggi sehingga dapat menyebabkan arduino panas

b) Serial Com

Komunikai serial arduino dengan PC dengan menggunaka USB. Perantaraan ini memanfaatkan bagian USB to UART converter yang ada pada arduino. Skematik rangkaian USB to UART ditunjukan oleh gambar III.7. Pin komunikasi UART arduino adalah pin 0 dan 1 dimana pin 0 adalah pin $R X$ dan pin 1 adalah pin TX. Pin RX arduino terhubung dengan pin TX (pin 1) IC FT232R dan pin TX arduino terhubung dengan pin RX(pin 5) IC FT232R. Kemudian oleh IC FT232R ini sinyal dirubah dari UART ke USB sesuai dengan protokol USB 2.0.

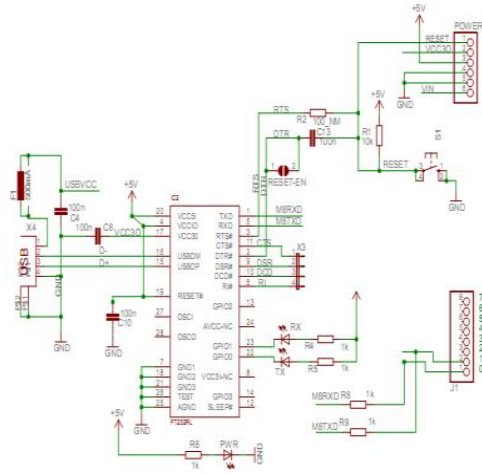

Gambar 7. Skematik konverter UART TTL ke USB pada Arduino

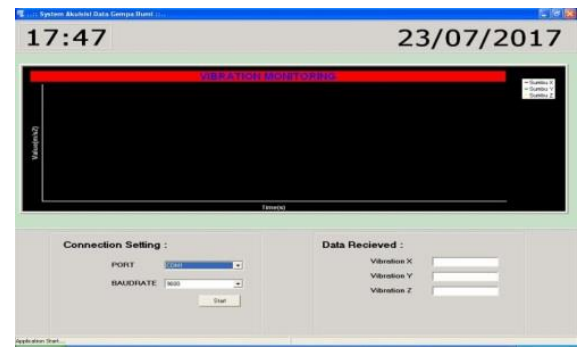

Gambar 8. Desain form aplikasi interface

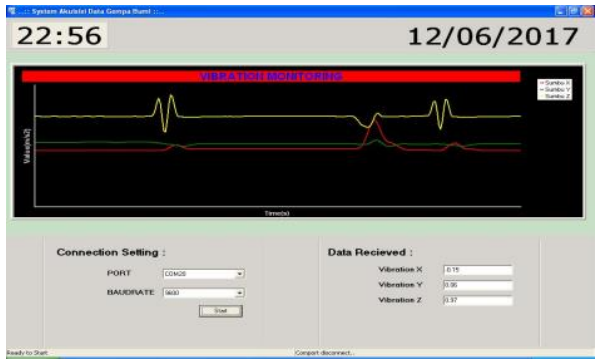

Gambar 9. Gambar hasil pembacaan alat

\section{E. KESIMPULAN}

Alat pendeteksi gempa menggunakan sensor 3accelerometer berbasis arduino dengan output serial com dan buzzer dapat didefinisikan, kesimpulan sebagai berikut:

1. Perancangan alat pendeteksi gempa menggunakan sensor 3accelerometer berbasis arduino dapat berjalan sesuai harapan peneliti.

2. Serial com akan menampilkan data getaran pada PC atau laptop jika terhubung dengan alat yang sudah terpasang.

3. Keluaran buzzer berupa suara sesuai interuksi program yang telah dimasukan dan pada tegangan 5 volt, dan jika tegangan kurang dari 5 volt maka buzzer tidak bekerja.

4. Pendeteksi gempa masih berupa prototype, yang akan bekerja setelah mendapat sensor pada alat.

5. Alat akan berfungsi jika mendapat gerakan pada sensor, dan buzzer akan bekerja jika 
gempa atau getaran sesuai dengan standar atau melebihi data yang dimasukan.

\section{DAFTAR PUSTAKA}

[1] Andre. 2015. Pengertian Bahasa Pemrograman Pascal. Diambil dari: http://www.duniailkom.com/tutorialbelajar-pascal-pengertian-bahasapemrograman-pascal/ diakses pada 29 juli 2017.

[2] Abdul Kadir. 2013. Panduan Praktis Mempelajari Aplikasi Mikrokontroler dan Pemrogramanya menggunakan Arduino. Yogyakarta :C.V.Andi Offset

[3] Anonim. 2009. Arduino Deumilanove Reference Design. Diambil dari: http://www.sparkfun.com/tutorials-arduino2009 diakses pada 2 agustus 2010

[4] Djuandi, Feri. 2011. Pengenalan Arduino. Jakarta : Penerbit Elexmedia

[5] Dicson,Kho.2014. Pengertian IC (Integrated Circuit) dan Aplikainya. Diambil dari:

http://teknikelektronika.com/pengertian-icintegrated-circuit-aplikasi-fungsi-ic/ di akses pada tanggal 20 Juli 2017

[6] Rida Angga. 2016. Pengertian Komponen Aktif dan Pasif Beserta Jenis dan Fungsinya. Diambil dari: http://skemaku.com/pengertiankomponen-aktif-dan-pasif-beserta-jenisdan-fungsinya/ diakses pada 20 Juli 2017

[7] Setiawan, M.Arif, dkk. 2011. Rancang Bangun Sistem Otomasi Rumah Berbasis Mikrokontroler. Politeknik Elektronika Negeri Surabaya.

[8] Yogi Dasatrio. 2013. Dasar - Dasar Teknik Elektronika. Yogyakarta: JAVALITERA

[9] Alexdumyati. 2014. Pengertian USB (Universal Serial Bus), Jenis - Jenis USB dan Perbedaanya. Diambil dari: https://alexdumyati17.wordpress.com/201 4/11/12/pengertian-usb-universal-serialbus-jenis-jenis-usb-dan-perbedaannya/ diakses pada 29 Juli 2016

[10] Hariz, Riandy. 2013. Pengertian dan Perinsip Kerja Buzzer. Diambil dari: http://r-dy-

techno.blogspot.co.id/2013/06/pengertiandan-prinsip-kerja-buzzer.html diakses pada 29 Juli 2016

[11] Febian. 2009. Elektronika dasar. Diambil dari: http://www.pusatgratis.com/ebookgratis/ebook-iptek/dasar-elektronikauntuk-pemula.html

[12] Anonim. 2017. Data Gempa di Indonesia Diambil dari: www.bmkg.go.id

[13] Anonim. 2017. Arduino. Diambil dari: www.arduino.cc 